ARTICLE INFO

Received

August 06, 2021

Revised

October 15, 2021

Accepted

October 17, 2021

Published

November 28, 2021

*Corresponding author

Rukhsar Shaheen

E-mail

doriskalele@gmail.com

Keywords

Leaf extract

Milky exudates

Seed germination

Seed priming

How to cite

Shaheen R. Evaluation of seed germination of Sorghum bicolor grown after priming with leaf extract and milky sap exudate of Calotropis procera.

Sci Lett 2021; 9(3):110-113
Open Access

\section{Evaluation of Seed Germination of Sorghum bicolor Grown After Priming with Leaf Extract and Milky Sap Exudate of Calotropis procera}

\section{Rukhsar Shaheen*, Ali Razzaq}

Department of Botany, University of Okara, Multan Road, Renala Khurd, Okara, Punjab, Pakistan

\section{Abstract}

A pot experiment was conducted to investigate the effect of priming with the extract of plant Calotropis procera on seed germination of Sorghum bicolor. The seeds of Sorghum bicolor were primed with different concentrations of Calotropis procera leaf extract and milky sap exudate for five days at different time intervals. In total, there were five groups of days and nine seed priming treatments. The result showed that maximum seeds were germinated on day 4 in all treatments, but it was not significantly different from day 2,3 , and day 5 . Whereas the highest germination of seeds was noted in two treatments, 24 hours priming with $100 \%$ boiled leaves extract (T3) and 24 hours priming with $100 \%$ milky exudate (T4), irrespective of priming days, except one day. These results showed that both milky exudate and boiled leaf extract have a positive effect on seed germination of Sorghum bicolor; therefore, in the future, both types of extracts of Calotropis procera should be considered important for priming the seeds of different plants to improve seed germination. 


\section{Introduction}

Seed priming is a pre-sowing treatment, in which, seeds are soaked in an osmotic solution that permits seeds to absorb water and go through the first stages of germination [1]. Seed priming enhances vigor for fast and strong plant development, enhances yield potential, enables seeds to germinate and emerge even under adverse agroclimatic conditions [2]. Recently, there has been an increased interest in seed soaking to improve establishment [3]. Though it is an old concept, significant progress has been made in developing seed soaking into a practical technology for use by small-holder farmers called on-farm seed priming [4]. It is an accepted fact that priming improves germination, reduces seedling emergence time and improves stand establishment [5]. Sorghum bicolor, commonly called sorghum plant, is an annual and short-term perennial grass species belonging to the family poaceae. It is also known as great millet, durra, jowar, or milo and is cultivated for its gains. Sorghum is the world's fifth-most important cereal crop after rice, wheat, maize, and barley. It is believed to have originated in Africa, particularly in Ethiopia and surrounding countries [6]. It is high in carbohydrates, protein, and fat, and contains calcium, iron and niacin. Dezfuli et al. [7] evaluated the influence of seed priming techniques on germination and early growth of plants and reported that priming techniques positively affect seed germination and early growth. Many recent researchers also suggested that seed priming of crop seeds might be a useful way for better germination, seedling growth, establishment, and yield [8].

In the family Apocynaceae, Calotropis procera is a species of flowering plants. A toxic milky sap is obtained from its green fruits that are extremely bitter. The reason for its toxicity is steroidal components that are the cause of its toxicity. Allelopathy is a natural phenomenon in which various organisms affect the functioning of other organisms by releasing secondary metabolites [9]. Some plants release chemical compounds from different parts into their environment and these compounds are often referred to as allelochemicals [10]. These are secondary metabolites secreted in very low amounts by plants but play a very important role in plant defense against pathogens or other abiotic factors [11]. These allelochemicals are alkaloids, phenolics, terpenoids, hydroxamic acids, salicylates, etc. In the present study, the leaf extract and milky sap exudate of medicinal plant Calotropis procera, locally called Aak, were used for seed priming and its effect on seed germination of Sorghum bicolor was evaluated.

\section{Materials and Methods}

\section{Site of experiment}

The experiment was conducted in the Environmental and Bio-Tech Laboratory of University of Okara, Renala Khurd, Punjab, Pakistan located at coordinates of $30^{\circ} 52^{\prime} 04.19^{\prime \prime} \mathrm{N}$ and $73^{\circ} 34^{\prime} 08.45^{\prime \prime} \mathrm{E}$.

\section{Selection of plant for seed priming}

The plant Sorghum bicolor was selected to evaluate the effect of seed priming, and its seeds were bought from the market.

\section{Preparation of extract and exudate}

The plant Calotropis procera was selected to obtain leaf extract and milky sap exudate as a priming agent. The plants were chosen from the sides of the road and canal of Depalpur, Pakistan. Fresh leaves and plant tips of Calotropis procera were collected for the plant extract and exudate collection. To collect the milky sap exudate, tips of Calotropis procera plant were pressed hard by hand and the white sap exudate was collected in a washed bottle, which served as the stock solution to prepare different dilutions $(10 \%, 50 \%, 100 \%)$. To prepare leaf extract, leaves of Calotropis procera were boiled in water for one hour and then filtered with cheesecloth to get water extract. The seeds were primed with $100 \%$ of leaf extract for 6 , 12 and 24 hours.

\section{Treatments}

Following treatments were organized for this experiment:

$\mathrm{T} 0=$ seeds without priming

$\mathrm{T} 1$ = priming for 6 hours with $100 \%$ of boiled leaves extract

$\mathrm{T} 2=$ priming for 12 hours with $100 \%$ of boiled leaves extract

$\mathrm{T} 3=$ priming for 24 hours with $100 \%$ of boiled leaves extract

$\mathrm{T} 4=$ priming for 24 hours with $100 \%$ milky sap exudate

T5= priming for 24 hours with $50 \%$ milky sap exudate 
Table 1 Average seed germination of Sorghum bicolor primed with leaf extract and milky sap exudate of Calotropis procera.

\begin{tabular}{|c|c|c|c|c|c|c|}
\hline \multirow[t]{2}{*}{ Treatments } & \multicolumn{6}{|c|}{ Time (days) } \\
\hline & 1 & 2 & $\mathbf{3}$ & 4 & 5 & mean \\
\hline T0 & ND & $3.00^{\mathrm{b}}$ & $3.33^{\mathrm{cd}}$ & $3.33^{\mathrm{cd}}$ & $3.30^{\mathrm{cd}}$ & $3.67^{\mathrm{D}}$ \\
\hline T1 & $1.67^{\mathrm{f}}$ & $4.67^{\mathrm{b}}$ & $4.67^{b}$ & $4.67^{\mathrm{b}}$ & $4.67^{b}$ & $4.07^{\mathrm{C}}$ \\
\hline $\mathbf{T 2}$ & $2.33^{\mathrm{e}}$ & $4.67^{b}$ & $4.67^{b}$ & $4.67^{b}$ & $4.67^{b}$ & $4.20^{\mathrm{B}}$ \\
\hline T3 & $4.00^{c}$ & $5.00^{\mathrm{a}}$ & $5.00^{\mathrm{a}}$ & $5.00^{\mathrm{a}}$ & $5.00^{\mathrm{a}}$ & $4.80^{\mathrm{A}}$ \\
\hline $\mathbf{T 4}$ & $2.67^{d}$ & $5.00^{\mathrm{a}}$ & $5.00^{\mathrm{a}}$ & $5.00^{\mathrm{a}}$ & $5.00^{\mathrm{a}}$ & $4.53^{\mathrm{AB}}$ \\
\hline T5 & ND & $5.00^{\mathrm{a}}$ & $5.00^{\mathrm{a}}$ & $5.00^{\mathrm{a}}$ & $5.00^{\mathrm{a}}$ & $4.00^{\mathrm{C}}$ \\
\hline T6 & $0.67^{\mathrm{g}}$ & $4.67^{\mathrm{b}}$ & $4.67^{\mathrm{b}}$ & $4.67^{\mathrm{b}}$ & $4.67^{\mathrm{b}}$ & $3.87^{\mathrm{CD}}$ \\
\hline T7 & $1.50^{\mathrm{f}}$ & $2.67^{d}$ & $3.00^{\mathrm{d}}$ & $3.00^{\mathrm{d}}$ & $3.00^{\mathrm{d}}$ & $2.63^{\mathrm{E}}$ \\
\hline T8 & $0.33^{\mathrm{h}}$ & $2.67^{\mathrm{d}}$ & $2.67^{d}$ & $2.67^{d}$ & $2.67^{d}$ & $2.20^{\mathrm{F}}$ \\
\hline T9 & ND & $1.67^{f}$ & $1.67^{f}$ & $2.00^{\mathrm{de}}$ & $2.00^{\mathrm{de}}$ & $1.50^{\mathrm{G}}$ \\
\hline mean & $1.31^{\mathrm{B}}$ & $3.90^{\mathrm{A}}$ & $3.97^{\mathrm{A}}$ & $4.00^{\mathrm{A}}$ & $3.99^{\mathrm{A}}$ & \\
\hline
\end{tabular}

$\mathrm{ND}=$ no data found; data are mean of three replicates; small letters show differences in overall data of all treatments and days, while capital English letters show differences in the means of treatments and time points, separately.

T6= priming for 24 hours with $10 \%$ milky sap exudate

$\mathrm{T} 7=$ priming with tap water for 24 hours

$\mathrm{T} 8=$ priming with tap water for 12 hours

$\mathrm{T} 9=$ priming with tap water for 6 hours

\section{Preparation of pots and data collection}

The medium for plant growth was prepared by mixing $70 \%$ clay and $30 \%$ sand thoroughly to get a homogeneous mixture and used to fill the $1 / 2$ liter plastic pots. After priming, five seeds were sown in each pot at an equal distance from each other. Each treatment has three replicates. Each pot was irrigated after every 24 hours with tap water regularly. The number of seeds germinated up to five days were counted and the mean values were presented.

\section{Results and Discussions}

The seed priming initiates the biochemical processes in seeds at the initial stage of germination by managing the temperature and moisture contents and bringing seeds closer to the germination stage [1]. In addition, during priming, seeds reach equally to the germination stage and uniform germination is possible. The use of water solutions containing salt, plant hormones or other chemicals is a common priming method. In addition, plant materials like plant extracts are also used as priming agents to improve the priming of seeds [12]. In this study, we also determined the effect of leaf extract and milky sap exude of a roadside plant Calotropis procera on the germination of seeds. The results of seed germination of Sorghum bicolor in different treatments are given in Table 1. The result showed that maximum seeds were germinated at day 4 in all treatments, but not significantly different from day 2, 3 and day 5. Whereas highest germination of seeds was noted in two treatments, 24 hours priming with $100 \%$ boiled leaves extract (T3) and 24 hours priming with $100 \%$ milky exudates (T4), irrespective of priming days, except one day. The extracts and parts of plant Calotropis procera have been reported beneficial as nematocidal, molluscidal and insecticidal agents, building material, adsorbent, animal feed, fuel, etc [13]. Here, the results showed that priming with the leaf extract and milky exudate could also be beneficial to improve seed germination of Sorghum bicolor, which would provide a good beginning for the rest of the plant growth stages. We recommend that leaf extract and milky exudate of plant Calotropis procera should also be tested for the seed priming of other important plant species.

\section{Conflict of Interest}

The authors declare that they have no conflict of interest

\section{References}

[1] Heydecker W. Germination of an idea: the priming of seeds. School of Agriculture Research, University of Nottingham, Nottingham. 1973; pp. 50-67.

[2] Harris, D. The effects of manure, genotype, seed priming, depth and date of sowing on the emergence and early growth of Sorghum bicolor (L.). Moench in semi-arid Botswana. Soil Till Res 1996; 40:73-88.

[3] Kidd F, West C. The influence of temperature on the soaking of seeds. New Phytol 1919; 18(1):35-39.

[4] Harris D, Joshi A, Khan PA, Gothkar P, Sodhi PS. On farming seed priming in semi-arid agriculture: 
development and evaluation in maize, rice and chickpea in India using participatory methods. Exp Agri 1999; 35:15-29.

[5] Nawaz J, Hussain M, Jabbar A, Abbas G, Muhammad N. Seed priming a technique. Inter J Agri Crop Sci 2013; 6(20):1373-1381.

[6] Kimber CT. Origins of domesticated sorghum and its early diffusion to India and China. In: Smith C, Frederiksen R, Smith WC (eds.). Sorghum: Origin, History, Technology and Production. John Wiley \& Sons, Inc. 2000; pp. 3-98.

[7] Dezfuli PM, Sharif-zadeh F, Janmohammadi M. Influence of priming techniques on seed germination behaviour of maize inbred lines. ARPN J Agric. Biol Sci 2008; 3:22-25.

[8] Ghiyasi M, Seyahjani AA, Tajbaksh M, Amirnia R and Salehzade H. Effect of osmopriming with polyethylene glycol on germination and seedling growth of wheat seeds under salt stress. Res J Biol Sci 2008; 3:1249-1251.

[9] Rice EL. Allelopathy, $2^{\text {nd }}$ edition. Academic Press, New york, USA; 1984.
[10] Farooq M, Jabran K, Chemma ZA, Wahid A, Kadambot HM. The role of allelopathy in agricultural pest management. Pest Manag Sci 2011; 67(5):493-506.

[11] Reigosa MS, Gonzalezy L, Souto XC, Pastoriza JE. Allelopathy in forest ecosystems. In: Narwal SS, Hoagland RE, Dilday RH, Reigosa MJ (eds.), Allelopathy in Ecological Agriculture and Forestry, Springer, Dordrecht; 2000.

[12] Zhu ZH, Sami A, Xu QQ, Wu LL, Zheng WY, Chen $\mathrm{ZP}$, et al. Effects of seed priming treatments on the germination and development of two rapeseed (Brassica napus L.) varieties under the co-influence of low temperature and drought. PLoS ONE 2021; 16(9):e0257236.

[13] Al Sulaibi MAM, Thiemann C, Thiemann T. Chemical Constituents and Uses of Calotropis Procera and Calotropis Gigantea - A Review (Part I-The Plants as Material and Energy Resources). Open Chem J 2020; 7:1-15. 